\title{
Kebijakan Pemerintah Daerah dalam Penanganan dan Perlindungan Anak yang Berhadapan dengan Hukum di Halmahera Utara
}

\author{
Sukitman Asgar ${ }^{1 *}$, Sahrestia Kartianti ${ }^{2}$ \\ ${ }^{1,2}$ Fakultas Ilmu Sosial dan Kependidikan Universitas Hein Namotemo, Tobelo Halmahera Utara \\ *Correspondence email: sukitman.asgar87@gmail.com, sahrestia.kartianti07@gmail.com
}

\begin{abstract}
Abstrak. Fenomena kekerasan anak di Halmahera Utara setiap tahun terus meningkat dan bahkan perbandingannya sangat siginifikan. Sehingga Perlunya keseriusan Pemerintah daerah untuk sedini mungkin mencegah terjadinya peningkatan kasus yang dialami oleh para anak melalui serangkaian upaya dan tindakan baik dalam bentuk sosialisasi maupun langkah strategis lainnya, pelayanan yang tidak optimal kepada para anak yang berhadapan dengan hukum juga dapat berpengaruh pada tumbuh kembangnya si anak terutama pada aspek pemulihan psikis dan kesehatan anak. Untuk mendapatkan hasil penelitian yang sempurna diperlukan data dan informasi yang akurat dan mendukung. Dengan demikian, Penelitian ini dilakukan melalui Pendekatan Kualitatif yang dianalisis secara yuridis sosiologis dengan berdasarkan ketentuan perundang-undangan dan terjun langsung kelapangan guna mengamati efektifitas penerapan hukum yang dilaksanakan instansi pemerintah daerah. Setelah dianalis melalui metode pendekatan serta data yang tersedia, terdapat beberapa hal yang belum terlaksana dengan baik. Artinya segala upaya dan kebijakan yang dilakukan pemerintah daerah dibidang perlindungan anak khususnya yang berhadapan dengan hukum belum sesuai harapan yang diamanatkan dan peraturan perundang-undangan. Dimana terdapat beberapa kasus kekerasan anak harus putus tengah jalan karena berbagai pertimbangan, serta perlunya produk hukum sejenis peraturan daerah untuk mengakomodasi dan memenuhi segala kepentingan dan hak-hak para anak.
\end{abstract}

Kata Kunci: Upaya, Pemerintah Daerah, Perlindungan Anak

Abstract. The phenomenon of child violence in North Halmahera Regency continues to increase every year and even the comparison is very significant. So the need for the seriousness of the local government to prevent an increase in cases experienced by children as early as possible through a series of efforts and actions both in the form of socialization and other strategic steps, non-optimal service to children who are in conflict with the law can also affect the development of children especially on the aspects of psychological recovery and children's health. To obtain perfect research results, accurate and supportive data and information are needed. Thus, this research is conducted through a Qualitative Approach which is analyzed juridically and sociologically based on statutory provisions and directly involved in observing the effectiveness of law implementation carried out by local government agencies. After being analyzed through the available approach and data, there are several things that have not been carried out properly. This means that all efforts and policies made by local governments in the field of child protection, especially those dealing with the law, have not met the expectations mandated by the laws and regulations. Where there are several cases of child abuse, they have to break up in the middle of the road due to various considerations, as well as the need for a legal product similar to regional regulations to accommodate and fulfill all the interests and rights of children.

Keywords: Efforts, Local Government, Child Protection

\section{PENDAHULUAN}

Negara sebagai Institusi tertinggi wajib melindungi setiap Anak yang lahir dan berkembang baik secara fisik maupun mental dengan segala upaya yang tegas dan komitmen dalam melindungi hak-hak anak di Indonesia melalui pembentukan Peraturan Perundang-undangan tentang Perlindungan Anak serta ketentuan hukum lainnya. Karena Anak merupakan suatu Karunia yang diberikan oleh Tuhan Yang Maha Esa, yang didalam dirinya melekat harkat dan martabat sebagai manusia yang seutuhnya. Nasib suatu bangsa juga terletak pada diri mereka, sebagaimana dikemukakan oleh Sutedjo bahwa Anak merupakan cerminan sikap hidup bangsa dan penentu perkembangan bangsa tersebut. ${ }^{1}$

Konvensi Hak Anak (KHA) Internasional yang merupakan cikal bakal lahirnya ketentuan Peraturan Perundangundangan di Indonesia, yang diratifikasi melalui Keputusan Presiden Nomor 36 Tahun 1990. Dalam Perjalanan Selajutnya hak-hak anak di Indonesia kemudian mendapat kedudukan yang memadai, hal ini dapat dilihat dengan adanya pembentukan aturan hukum tentang anak. Namun demikian Implementasi ketentuan perundang-undangan tersebut tidak berjalan secara maksimal sesuai dengan amanat yang terkandung di dalamnya, khususnya pada daerahdaerah terpencil dan jauh dari Ibukota Negara seperti halnya di wilayah Halmahera yang luput dari pemberitaan dan perhatian media. 
Sukitman Asgar dan Sahrestia Kartianti, Kebijakan Pemerintah Daerah dalam Penanganan dan Perlindungan Anak yang Berhadapan dengan Hukum di Halmahera Utara

Sejatinya jaminan negara terhadap perlindungan anak sejak jauh hari pada masa kemerdekaan Indonesia telah diatur dengan tegas dalam konstitusi, terdapat dalam Alinea ke-empat Mukaddimah UUD 1945, yang berbunyi;

"Kemudian daripada itu untuk membentuk suatu susunan pemerintahan negara Indonesia yang melindungi segenap bangsa Indonesia dan seluruh tumpah darah Indonesia dan untuk memajukan kesejahteraan umum, mencerdaskan kehidupan bangsa dan ikut melaksanakan ketertiban dunia yang berdasarkan kemerdekaan, perdamaian abadi, dan keadilan sosial......"

Sebagai suatu komponen penting dalam negara. Pemerintah wajib menjamin terselenggaranya jaminan perlindungan anak itu sendiri, melalui Kebijakan-kebijakan yang dilakukan agar Implementasi Ketentuan Perundangundangan yang dapat berjalan seoptimal mungkin. Menurut Ahmad Kamil Perlindungan Anak merupakan pertanggungjawaban orang tua, keluarga, masyarakat, pemerintah dan negara yang merupakan rangkaian kegiatan yang dilaksanakan secara terus menerus demi terlindunginya hak-hak anak. ${ }^{2}$

Kabupaten Halmahera Utara, adalah sebuah daerah yang jauh dari ibukota Negara yang letaknya di wilayah timur Indonesia tepatnya Provinsi Maluku Utara. Hal inilah membuat poses pemenuhan hak anak yang mengalami korban maupun pelaku kekerasan tidak tersentuh oleh negara, sehingga menyebabkan berbagai kasus Pelanggaran anak di Halmahera Utara tidak mendapatkan pelayanan Hukum dan Konseling dari Pemerintah Daerah dengan optimal pada tahap penyidikan, penuntutan hingga pada proses Peradilan, yang semestinya harus didampingi sebagai bagian dari tanggung jawab negara kepada warga negara sebagaimana ketentuan UU Nomor 23 tahun 2014 tentang Pemerintah daerah junto UU Nomor 35 tahun 2014 perubahan atas 23 tahun 2002 tentang Perlindungan Anak.

Kondisi sosial masyarakat yang berbeda juga harus menjadi fokus pemerintah daerah dalam setiap merumuskan sebuah kebijakan terutama berhubungan dengan penyelesaian kekerasan anak. Seringkali corak budaya dan kondisi ekonomi ini luput dari perhatian Pemda sehingga kebijakan yang diambil kadang tidak berjalan maksimal karena terbentur dengan dengan kemauan dan kondisi masyarakat setempat yang dalam hukum dinamai aspek sosiologis hukum, belum lagi anak yang hanya dijadikan sebagai objek kebijakan tanpa melibatkan mereka kedalam hal-hal yang postif berdasarkan usia dan tumbuh kembang anak itu sendiri. Persoalan lainnya adalah segala kebijakan pemerintah daerah kadang hanya dilakukan sebagai sebuah proyek infrastruktur negara, setelah dilaksanakan atau dibuat tanpa perhatian selanjutnya misalnya melaksanakan sosialisasi terkait Perlindungan Anak maupun membuat dan mendirikan sebuah forum atau lembaga yang konsen pada pemenuhan hak-hak anak yang dalam pikiran pemerintah asalkan sudah berbuat selanjutnya terserah masyarakat sendiri apakah mau ikuti, mau sadar dan lainnya itu tidaklah penting. Mindset berpikir inilah yang menjadi persoalan dasar sehingga perlu diubah oleh seluruh komponen khususnya dalam melakukan pelayanan dan perlindungan anak. Hal lainnya adalah lemahnya kordinasi dan sinergitas para penegak hukum dalam menangani kekerasan anak yang berhadapan dengan hukum, sehingga mengakibatkan kekerasan anak di daerah ini khususnya korban setiap tahun melonjak tajam karena tidak ada efek yang berarti buat mereka saat melakukan perbuatan pelanggaran dan kekerasan anak. ${ }^{3}$

Dalam suatu kesempatan kunjungan Komisi Nasional Perlindungan Anak Indonesia ke kabupaten Halmahera Utara menyatakan bahwa Halmahera Utara merupakan suatu daerah yang masuk kategori darurat pelanggaran anak, dengan fakta meningkatnya kekerasan anak yang begitu signifikan karena kebiasaan anak yang terus menghisap lem aibon yang dianggap merupakan sebuah kenakalan remaja sehingga sulit dilakukan penanganan dan penegakan secara hukum karena tidak tersedianya payung hukum sejenis peraturan daerah, fakta lainnya yaitu penyelesaian kasus kekerasan anak kerap dilakukan melalui pendekatan hukum adat yang berujung pada pencabutan laporan sehingga dianggap telah damai dengan pelaku perbuatan kekerasan pada anak itu sendiri. ${ }^{4}$

Dari pada itu perlunya ada upaya Pemerintah Daerah secara serius agar tercapainya jaminan perlindungan hukum terhadap para anak melalui kebijakan-kebijakan yang pro terhadap permasalahan anak, baik kebijakan melalui pembentukan aturan tekhnis Peraturan Daerah yang dapat mengkomodisi seluruh kepentingan dengan memperhatikan kondisi sosial masyarakat sendiri maupun peningkatan Pelayanan dan Pendampingan tehadap mereka yang berhadapan dengan hukum, serta adanya peningkatan Sosialisasi kepada masyarakat, orang tua maupun kepada seluruh pihak sebagai upaya pencegahan terjadinya konflik hukum yang dialami seorang anak khususnya di Kabupaten Halmahera Utara.

Penelitian ini bertujuan menelaah aspek hukum terkait dengan perlindungan anak serta segala upaya yang dilakukan pemerintah daerah dalam rangka memenuhi hak-hak anak yang berhadapan dengan hukum sebagaimana

2. Ahmad Kamil dan Fauzan. Hukum Perlindungan dan Pengangkatan Anak di Indonesia. Raja Grafindo Persada. Jakarta 2008, hlm. 5

3 . Lihat, https://harianhalmahera.com: Kasus-kekerasan-anak-di-halut-terus-meningkat/ diakses pada 10/08/2020

${ }^{4}$. https://nusantaranews86.com/Halmahera Utara Darurat Pelanggaran Anak.html. diakses pada 112/08/2020 puku 15.00 
Sukitman Asgar dan Sahrestia Kartianti, Kebijakan Pemerintah Daerah dalam Penanganan dan Perlindungan Anak yang Berhadapan dengan Hukum di Halmahera Utara

tanggungjawab pemerintah daerah yang dijelaskan ketentuan undang-undang nomor 23 tahun 2014 tentang pemerintahan daerah serta undang-undang nomor 35 tahun 2014 perubahan atas undang-undang nomor 23 tahun 2002 tentang perlindungan anak serta peraturan perundang-undangan lainnya

\title{
METODE
}

Penelitian ini dilakukan dengan menggunakan jenis penelitian kualitatif. Dimana segala data yang telah didapatkan kemudian diolah secara deskriptif tanpa menjabarkan angka-angka dalam setiap permasalahan hukum yang dihadapi oleh para anak. Namun hanya dilakukan sebagai simple pada setiap kasus (Case Approach).

Metode pendekatan yang digunakan dalam penelitian ini adalah: Pendekatan Yuridis Empiris atau Normatif sosiologis. Penelitian yang dilakukan dengan pendekatan aturan-perundang-undangan serta terjun langsung kelapangan guna mengetahui gejala hukum pada masyarakat dengan cara observasi dan wawancara. Dari hasil observasi dan keterangan responden itulah kita bisa melihat kolerasi antara hukum dengan masyarakat, sehingga mampu mengungkap efektifitas berlakunya hukum dalam masyarakat. ${ }^{5}$ Sementara bahan hukum yang digunakan adalah Jenis bahan hukum Primer yang ditemukan secara langsung melalui observasi dan wawancara pada Dinas Pemberdayaan Perempuan Perlindungan Anak dan Keluarga Berencana P3A dan KB, Kepolisian dan Pengadilan Negeri Tobelo. Sementara jenis data/bahan hukum sekunder ditemukan melalui studi kepustakaan dan aturan perundang-undangan serta kamus hukum dan eksopedia media.

Adapun sumber data yang digunakan disini adalah sumber data primer dan sumber data sekunder. Sumber data primer yaitu undang-undang, catatan resmi, risalah dalam pembuatan perundang-undangan yakni UUD Tahun 1945, UU Nomor 23 tahun 2014 tentang Pemerintahan Daerah, UU Nomor 35 tahun 2014 tentang Perlindungan Anak, undang-undang nomor 11 tahun 2012 tentang Sistem Peradilan Pidana Anak serta Ketentuan Perundang-Undangan turunan lainnya yang terkait. Sedangkan Sumber data sekunder yaitu, semua literatur-literatur tentang hukum yang berkaitan dengan permasalahan yang dibahas. Adapun sumber sekunder adalah sebagai berikut: Konsep Kebijakan, Perlindungan hukum bagi anak, Peradilan pidana anak di Indonesia serta Sumber data Sekunder sebagai petunjuk untuk mengungkap fakta hukum dalam masyarakat diantaranya: Kamus Hukum, Media dan Eksopedia. Lokasi penelitian dilakukan di masing masing satuan kerja yakni, Pemerintah Daerah, Polres Halmahera Utara, Pengadilan Negeri Tobelo yang serta keterangan tambahan dari berbagai Pemerhati dan Aktivis Perlindungan Anak di Halmahera Utara.

\section{HASIL DAN PEMBAHASAN: \\ Prinsip Dasar Perlindungan Anak di Indonesia}

Negara sebagai Otoritas tertinggi dan Pancasila sebagai Fundamental Norm atau Hukum Dasar, merupakan sebuah penghayatan dan pelaksanaan segala rumusan sila yang terkandung didalamannya bagi segenap warga negara termasuk pemerintah. Sila ke kedua Pancasila berbunyi "Kemanusiaan yang adil dan beradab" merupakan sebuah falsafah bahwa segala aspek kehidupan bernegara dimemungkinkan tidak terdapat diskriminasi satu dengan lainnya dan menjunjung tinggi kemanusiaan yang merupakan Mahluk Ciptaan yang paling sempurna yang dilandasi akal dan pekiran. Atas dasar itu, sila ini kemudian diwajewentakan kedalam Konstitusi, Alinea ke-4 UUD tahun 1945 yang berbunyi:

\begin{abstract}
"Kemudian daripada itu untuk membentuk suatu susunan pemerintahan negara Indonesia yang melindungi segenap bangsa Indonesia dan seluruh tumpah darah Indonesia dan untuk memajukan kesejahteraan umum, mencerdaskan kehidupan bangsa dan ikut melaksanakan ketertiban dunia yang berdasarkan kemerdekaan, perdamaian abadi, dan keadilan sosial......"
\end{abstract}

Bahwa fungsi dan tujuan negara yang terkandung didalam alinea ke empat ini perlunya dipahami oleh semua elemen bangsa dalam rangka melakukan perlindungan dan mencerdaskan kehidupan bangsa untuk kesejahteraan bersama. Sehingga menjadi prinsip dasar negara yang harus dipegang guna melindungi anak dari tindak kekerasan dengan upaya memenuhi hak-hak para anak. Sejalan dengan hal tersebut, pasal 28 ayat (2) UUD tahun 1945 menyatakan bahwa, Setiap anak berhak atas kelangsungan hidup, tumbuh, dan berkembang serta berhak atas perlindungan dari kekerasan dan diskriminasi. Menurut Jimly Asshiddiqieu hak konstitusional (constitutional right) adalah hak-hak yang dijamin di dalam dan oleh UUD Negara Kesatuan Republik Indonesia 1945 baik dinyatakan secara tegas maupun tersirat, karena dicantumkan ke dalam konstitusi maka ia menjadi bagian dari konstitusi. Adanya Pengakuan dan penghormatan terhadap hak-hak konstitusioanl sebagai bagian dari konstitusi dan sebagai pembatasan terhadap kekuasaan negara. Terdaftarnya HAM kedalam konstitusi tertulis berarti memberi kedudukan bahwa hak-hak

5. Bandingkan dengan Soerjono Soekanto dan Sri Pamudji, Penelitian Hukum Normatif suatu Tinjauan Singkat, Raja Grafindo, Jakarta 2012, hlm. 42 
itu sebagai hak-hak konstitusional. Kontitusi merupakan hukum dasar atau hukum fundamental (fundamental law) maka hak-hak konstitusional juga mendapatkan kedudukan sebagai hak fundamental. ${ }^{6}$

Rumusan Pasal 28 tersebut menjadi landasan konstitusional negara untuk menjamin kelangsungan hidup yang layak terhadap para anak. Jaminan itu kemudian diproduksikan kedalam berbagai macam ketentuan peraturan perundang-undangan sebagai upaya perlindungan dan pemenuhan hak-hak para anak Indonesia, sebagaimana diatur dalam pasal 1 ayat (2) undang-undang nomor 23 tahun 2002 yang telah diubah dengan undang-undang nomor 35 tahun 2014 bahwa perlindungan anak adalah segala kegiatan untuk menjamin dan melindungi anak dan hak-haknya agar dapat hidup, tumbuh, berkembang, dan berpartisipasi, secara optimal sesuai dengan harkat dan martabat kemanusiaan, serta mendapat perlindungan dari kekerasan dan diskriminasi. Ahmad Kamil berpendapat bahwa Perlindungan Anak merupakan tanggungjawab orang tua, keluarga, masyarakat, pemerintah dan negara yang merupakan rangkaian kegiatan untuk secara terus menerus agar hak-hak anak dapat terlindungi. ${ }^{7}$

Perlindungan terhadap anak mestilah diberikan kepada setiap anak, baik dari orang tua yang merupakan orang terdekat dari anak, keluarga, dan yang paling penting untuk mendapatkan kepastian hukum adalah perlindungan yang diberikan oleh pemerintah dan isntansi terkait lainnya. Hal ini akan sangat berdampak positif guna pengurangan terjadinya kekerasan terhadap anak. Oleh Arif Gosita bahwa perlindungan anak adalah suatu usaha melayani dan melindungi anak agar dapat melaksanakan hak dan kewajibannya, agar bebas mengekspresikan dirinya baik dibidang sosial maupun pada dirinya sendiri. Perlindungan anak juga menyangkut kebutuhan jasmani dan rohaninya sehingga perkembangan anak tidak mengalami gangguan dan hambatan dalam setiap perkembangannya. ${ }^{8}$

\section{Tanggungjawab Pemerintah Daerah dalam Bidang Perlindungan Anak}

Pemerintah merupakan suatu komponen penting untuk menjamin terselenggaranya Pemenuhan Hak Anak di Indonesia. Namun dengan melihat negara Indonesia yang sangat luas, menuntut seorang presiden yang kesehariannya sebagai kepala pemerintahan sekaligus kepala negara tidaklah mungkin hanya dibantu dengan seorang wakil presiden dan kementerian lembaga dan institusi lainnya yang berkedudukan sebagai pemerintah pusat. Dengan demikian, untuk kemudahan dan kelancaran tugasnya sebagai seorang kepala pemerintahan, maka dibentuklah satuan penyelenggaraan pemerintahan di daerah. Sehingga kewenangan dan sebagian tugasnya diserahkan kepada pemerintah bersangkutan baik tingkat provinsi adalah Gubernur dan DPRD maupun kabupaten/kota adalah Walikota/Bupati dan DPRD berdasarkan prinsip otonomi, asas desentralisasi, dan tugas pembantuan. Hal ini dimaksudkan untuk mempermudah rentang kendali penyelenggaraan pemerintahan dan pelayanan publik serta mempercepat akses pembangunan kepada masyarakat agar terciptanya negara Indonesia yang sejahtera sesuai dengan cita-cita dan tujuan negara yang termaktub dalam alinea ke IV Mukaddimah UUD $1945^{9}$.

Bertalian dengan hal itu, salah satu fungsi pemerintah adalah menjalankan tugas-tugas esensial dan fakultif yang dibutuhkan negara agar tetap berdaulat dan sejahtera. Tugas esensial atau tugas asli negara dari pemerintah adalah mempertahankan negara agar tetap diakui dan berdaulat, sedangkan tugas fakultif negara adalah agar rakyat tetap dalam koridor sejahtera baik secara umum, pendidikan, logika, etika, estetika, hukum, ekonomi, agama ,seni budaya dan lainnya...". ${ }^{10}$

Pemerintahan daerah merupakan suatu kesatuan dengan pemerintahan pusat yang tanggung jawab dan pelaksanaan pemerintahannya berpedoman pada norma dan standar yang ditetapkan oleh pemerintah pusat, karena tugas akhir dalam pemerintahan daerah adalah pada presiden Republik Indonesia. Pemerintahan daerah ditempatkan sendiri dalam konstitusi Republik Indonesia yang mana terdapat pada Bab VI UUD 1945 tentang Pemerintahan Daerah. Dalam perubahan kedua, Pasal 18 dinyatakan ${ }^{11}$ :

1. Negara Kesatuan Republik Indonesia dibagi atas daerah-daerah provinsi dan daerah provinsi itu dibagi atas kabupaten dan kota, yang tiap-tiap provinsi, kabupaten, dan kota itu mempunyai pemerintahan daerah, yang diatur dengan undang-undang.

6. Felda Rizki Azelia, Perlindungan Hukum terhadap Anak sebagai Korban Kekerasan yang terjadi di Sekolah, Jurnal Wajah Hukum Vol. 4 Nomor 1 tahun 2020, hlm. 173

7. Ahmad Kamil, Hukum Perlindungan dan Pengangkatan Anak di Indonesia. Raja Grafindo Persada. Jakarta 2008. hlm. 5

8. Anggung Lestari Perlindungan Hukum Preventif Terhadap Kekerasan Perempuan Dan Anak Dalam Perspektif Hukum Hak Asasi Manusia, Marwah: Jurnal Perempuan, Agama dan Jender. Vol. 16, No. 2 tahun 2017, hlm. 122

9. Lihat Pembukaan UUD 1945, bandingkan dengan Sukitman Asgar, Penyelenggaraan Pemerintahan Daerah berdasarkan Pasal 18 UUD tahun 1945 Jo UU Nomor 23 tahun 2014 tentang Pemerintahan Daerah, Jurnal Hibualamo, Vol. 1 Nomor 1 tahun 2017, hlm. 1

10. Op.Cit

11. Lihat Pasal 18 UUD 1945, Perubahan kedua menempatkan daerah memiliki eksistensi yang nyata dan diakui oleh negara dengan prinsip otonomi. 
Sukitman Asgar dan Sahrestia Kartianti, Kebijakan Pemerintah Daerah dalam Penanganan dan Perlindungan Anak yang Berhadapan dengan Hukum di Halmahera Utara

2. Pemerintahan daerah provinsi, daerah kabupaten, dan kota mengatur dan mengurus sendiri urusan pemerintahan menurut asas otonomi dan tugas pembantuan.

3. Pemerintahan daerah provinsi, daerah kabupaten, dan kota memiliki Dewan Perwakilan Rakyat Daerah yang anggota-anggotanya dipilih melalui pemilihan umum.

4. Gubernur, bupati, dan walikota masing-masing sebagai kepala pemerintah daerah provinsi, kabupaten, dan kota dipilih secara demokratis.

5. Pemerintahan daerah menjalankan otonomi seluas-luasnya, kecuali urusan pemerintahan yang oleh UndangUndang ditentukan sebagai urusan pemerintah pusat.

6. Pemerintahan daerah berhak menetapkan peraturan daerah dan peraturan-peraturan lain untuk melaksanakan otonomi dan tugas pembantuan.

7. Susunan dan tata cara penyelenggaraan pemerintahan daerah diatur dalam Undang-Undang.

Bertalian dengan Kontitusional Pasal 18 ini sudah barang tentu menjadi tanggung jawab pemerintah daerah untuk menjalankan segala norma dan standar yang ditentukan oleh negara dan pemerintah pusat, karena tugas akhir segala urusan pemerintahan adalah presiden dan kementerian lembaga yang bernaung sebagai pemerintah pusat.

Harris menyatakan bahwa pemerintahan daerah (local self goverment) pemerintahan yang diselenggarakan oleh badan-badan daerah yang dipilih secara bebas dengan tetap mengakui supremasi pemerintahan nasional. Pemerintahan ini diberi kekuasaan, diskresi, dan tanggung jawab tetap dikontrol oleh kekuasaan yang lebih tinggi. ${ }^{12}$

Sebagai salah satu Kabupaten wilayah Timur Indonesia. Pemerintah daerah pada beberapa tahun terakhir intens melakukan kegiatan yang pro terhadap anak. Sebagaimana tanggung jawab kewenangan pemerintah daerah yang diatur dalam UU Nomor 23 tahun 2014 tentang Pemerintahan daerah pasal 12 ayat (2) huruf b yang mengatur pembagian kewenangan perlindungan anak antara pemerintah pusat, Provinsi, serta kabupaten dan kota beserta lampirannya junto undang-undang nomor 35 tahun 2014 tentang perlindungan anak. Tanggung jawab pemerintah Daerah tersebut kemudian dijabarkan melalui berbagai upaya yaitu dilakukan dengan bentuk pencegahan diantaranya mengsosialisasikan ketentuan aturan perundang-undangan serta dampaknya secara psikis maupun fisik terhadap pelaku kekerasan terhadap anak sebagai bagian dari mencegah tindak kekerasan terhadap anak.

Instrumen yuridis sebagaimana ditentukan dalam pasal 21 undang-undang nomor 35 tahun 2014 tentang perlindungan anak secara jelas mengingatkan dan menegaskan tanggungjawab dan kewajiban pemerintah daerah untuk selalu memberikan pelayanan terbaik kepada para anak, bahwa kewajiban dan tanggung jawab negara, pemerintah pusat dan pemerintah daerah adalah sebagai berikut:

1. Negara, Pemerintah, dan Pemerintah Daerah berkewajiban dan bertanggung jawab menghormati pemenuhan Hak Anak tanpa membedakan suku, agama, ras, golongan, jenis kelamin, etnik, budaya dan bahasa, status hukum, urutan kelahiran, dan kondisi fisik dan/atau mental.

2. Untuk menjamin pemenuhan Hak Anak sebagaimana dimaksud pada ayat (1), negara berkewajiban untuk memenuhi, melindungi, dan menghormati Hak Anak.

3. Untuk menjamin pemenuhan Hak Anak sebagaimana dimaksud pada ayat (1), Pemerintah berkewajiban dan bertanggung jawab dalam merumuskan dan melaksanakan kebijakan di bidang penyelenggaraan Perlindungan Anak.

4. Untuk menjamin pemenuhan Hak Anak dan melaksanakan kebijakan sebagaimana dimaksud pada ayat (3), Pemerintah Daerah berkewajiban dan bertanggung jawab untuk melaksanakan dan mendukung kebijakan nasional dalam penyelenggaraan Perlindungan Anak di daerah.

5. Kebijakan sebagaimana dimaksud pada ayat (4) dapat diwujudkan melalui upaya daerah membangun kabupaten/kota layak Anak.

Implementasi dari ketentuan diatas melalui Dinas Pemberdayaan Perempuan, Perlindungan Anak dan Keluarga Berencana P3A dan KB Kabupaten Halmahera Utara telah merumuskan kebijakan yang berkaitan dengan perlindungan anak. Sebagaimana diutarakan oleh Kadis PPA dan KB Ibu Syarifa Hi. Ahmad pada Senin 6/9/2020:

"Pemda Halut khususnya kami di Dinas P3A dan KB bahwa, untuk pencegahan kekerasan anak telah kami lakukan dengan maksimal baik dalam bentuk sosialiasi, pembentukan PATB (Perlindungan Terpadu Berbasis Masyarakat) di setiap Desa maupun pembentukan Forum Anak yang di SK kan langsung oleh Bupati Halmahera Utara, hal ini dilakukan guna meningkatkan peran serta masyarakat dalam memberikan kenyamanan dari lingkungan keluarga dan masyarakat pada umumnya". 
Pembentukan Forum Perlindungan Terpadu Berbasis Masyarakat adalah sebuah forum kerjasama Pemerintah daerah dan pemerintah desa untuk meningkatkan peran serta dan menumbuhkembangkan keterlibatan masyarakat secara langsung dalam membantu dan mendukung pemerintah melakukan perlindungan anak yang sumber anggarannya diploting langsung dari Dana Desa. Kebijakan yang dilakukan ini merupakan sebuah upaya guna memberikan pemahaman kepada masyarakat tentang pentingnya perlindungan dan pemenuhan hak-hak anak khususnya dilingkungan keluarga maupun sosial, serta akibat hukum yang ditimbulkan dari perbuatan kekerasan yang dilakukan terhadap para anak itu sendiri. Dengan demikian semboyan Dinas P3A Kabupaten Halmahera Utara adalah "setiap anak adalah anak sendiri bagi semua orang". Namun hal ini hanyalah merupakan slogan pemerintah daerah tanpa terobosan nyata yang dilakukan secara simultan dalam upaya memenuhi hak-hak dan kepentingan anak.

Bertalian dengan hal tersebut, menurut penulis upaya dan langkah-langkah yang dilakukan dianggap belumlah berhasil karena tidak berbanding lurus dengan grafik kekerasan anak di Kabupaten Halmahera Utara hingga berbuntut pada proses hukum kepada mereka. Hal itu karena dilakukan tidak berdasar pada pemetaan masalah serta pendekatan dan strategi yang baik dengan kata lain tidak berdasarkan pada kondisi sosial dan budaya pada masyarakat sebagai objek kebijakan, serta perlunya perangkat atau produk hukum sejenis peraturan daerah yang didalamnya mengatur kondisi sosial, ekonomi budaya dan lainnya termasuk proses dan pendampingan hukum kepada mereka baik sebagai korban maupun pelaku kekerasan pada anak. Sebagaimana diungkapkan oleh Saefullah Yophi bahwa,

\begin{abstract}
"Akibat lemahnya perlindungan hukum dan sosial terhadap anak ditambah sistem budaya di masyarakat menjadikan posisi anak sangat rentan terhadap ancaman dan serangan kekerasan, baik fisik, seksual maupun psikologis serta meningkatnya perdagangan orang khususnya anak, menjadikan kekerasan terhadap anak cenderung meningkat............" 13
\end{abstract}

Ketidak berhasilannya Pemerintah Daerah dibuktikan juga dengan tidak adanya upaya membuat kehidupan anak lebih nyaman terhadap lingkungan seperti penyediaan Taman Bermain Anak khususnya di Ibukota Kabupaten di Tobelo hingga pada Pembentukan Rumah Aman bagi anak korban Kekerasan, sebagaimana diutarakan oleh Pemerhati Anak yang juga Direktur Lembaga Bantuan Hukum LBH Rakyat Halut Egbert Hoata saat diwawancarai menyatakan bahwa ada suatu peristiwa kekerasan dibidang pelecehan seksual putus tengah jalan akibat dari tidak tersedianya Rumah Aman bagi korban kekerasan anak, sehingga korban cenderung ditekan oleh keluarga agar tidak melaporkan kejadian yang dialaminya, karena pelakunya orang terdekat korban sendiri. Saat LBH Rakyat Halut mengamankan yang bersangkutan dari bawah tekanan keluarga, malah LBH tersebut dilaporkan atas tindakan penculikan Anak. ${ }^{14} \mathrm{Hal}$ ini perlunya perhatian Pemerintah Daerah untuk sedapat mungkin mendirikan rumah aman atau rumah singgah sementara waktu bagi si anak.

Darurat kekerasan anak di Kabupaten Halmahera Utara membawa kecemasan tersendiri bagi keluarga dan masyarakat secara umum, oleh karena itu perlunya pro aktif dari Pemerintah Daerah dalam upaya melindungi dan memenuhi hak-hak anak baik secara psikis maupun sosial terhadap para anak yang mengalami kekerasan langsung, yang tidak sebatas memberikan pencegahan melalui sosialisasi dan lainnya. Namun harus didukung dengan langkahlangkah yang tepat dan strategisi, hal ini sebagai bentuk keseriusan pemerintah daerah atas tanggung jawab yang diamanahkan dalam ketentuan Peraturan Perundang-undangan khususnya Pasal 21 ayat 5 UU Nomor 35 tahun 2014 tentang Daerah Layak Anak.

\title{
Kebijakan Pemerintah Daerah terhadap Anak yang Berhadapan Dengan Hukum
}

Perbedaan mendasar antara manusia dengan makhluk hidup lainnya adalah manusia diberikan akal dan nafsu. Nafsu seringkali mampu mengalahkan akal ketika keduanya diperhadapkan dalam suatu persoalan yang sulit, sehingga dengan nafsu manusia dapat pula berbuat sesuai keinginannya tanpa memikirkan dampak yang terjadi. Untuk menjaga keseimbangan itu, maka sangat dibutuhkan sebuah alat/sarana yang mampu memberikan pengaturan yang dalam kehidupan keseharian disebut dengan Hukum.

Hukum dapat memberikan kenyamanan hidup serta sebagai sarana rekayasa sosial kemasyarakatan untuk kepentingan hidup warga negara dalam mencapai kebahagiaan didunia melalui hukum negara dan kebahagiaan akhirat melalui hukum Allah. ${ }^{15}$ Menurut berbagai pandangan ahli hukum bahwa tidak seorangpun mampu memberikan definisi hukum yang dapat diterima oleh semua khalayak, namun penulis mencoba memberikan gambaran dengan

13. Syaifullah Yophi Ardianto, Perlindungan Hukum Terhadap Anak sebagai Korban dari Tindak Pidana Perdagangan Orang Di Kota Pekanbaru, Jurnal Ilmu Hukum. VOL. 3, No. 1, tahun 2013, hlm. 12

14. Lihat juga. http://radiosyallom.com/LBH minta Penegak Hukum Bertindak atas maraknya Kekerasan anak di Halut.html diakses pada tanggal 10 Oktrober 2020

${ }^{15}$. Bandingkan dengan Rescue Pound, (Law as tool of social engineriing) dalam Lili Rasidji Dasar-dasar Filsafat Hukum, Citra Aditya, 1999, hlm. 47 
meminjam sebuah definisi dari Enrst Utrecht seorang ahli hukum Belanda yang menyatakan bahwa hukum adalah himpunan petunjuk hidup yang mengatur tata tertib dalam suatu masyarakat dan seharusnya ditaati oleh anggota masyarakat yang bersangkutan, oleh karenanya pelanggaran terhadap petunjuk hidup itu dapat menimbulkan tindakan dari pemerintah/ masyarakat itu. Sunaryati Hartono memberikan definisi mengenai Pengertian Hukum yaitu hukum itu tidak menyangkut kehidupan pribadi seseorang, akan tetapi jika mengatur berbagai aktivitas manusia dalam hubungannya dengan manusia lainnya, atau dengan kata lain hukum mengatur berbagai aktivitas manusia di dalam hidup bermasyarakat. ${ }^{16}$

Istilah kebijakan seringkali kita dengar dalam setiap rencana dan tindakan yang dilakukan oleh birokrasi pemerintahan. Menurut Anderson yang dikutip oleh Budi Winarno menyatakan, terdapat 3 sifat kebijakan publik sebagai arah tindakan diantaranya:

1. Segala tuntutan kebijakan (policy demands) yaitu tuntutan-tuntutan yang dibuat oleh para aktor dalam sebuah lingkungan pemerintah maupun swasta untuk sebuah roda organisasi yang lebih baik

2. Keputusan kebijakan (policy demands) didefinisikan sebagai keputusan-keputusan yang dibuat oleh pejabat-pejabat pemerintah yang mengesahkan atau memberi arah dan substansi kepada tindakan-tindakan kebijkan publik termasuk dalam kegiatan ini adalah menetapkan undang-undang, memberikan perintah-perintah eksekutif atau penyataan-pernyataan resmi, mengumumkan peraturan-peraturan administratif atau membuat interpretasi yuridis terhadap undang-undang.

3. Pernyataan-pernyataan kebijakan (policy statement) adalah pernyataan-pernyataan resmi atau artikulasi-artikulasi kebijakan publik yang termasuk dalam kategori ini adalah undang-undang legislatif, perintah-perintah dan Tahap Evaluasi Kebijakan Pada tahap ini kebijakan yang telah dijalankan akan dinilai atau dievaluasi, hal ini dilakukan untuk melihat sejauh mana kebijakan yang dibuat telah mampu memecahkan masalah. ${ }^{17}$

Perlindungan hukum adalah memberikan pengayoman kepada hak asasi manusia yang dirugikan orang lain dan perlindungan tersebut diberikan kepada masyarakat agar mereka dapat menikmati semua hak-hak yang diberikan oleh negara atau dengan kata lain berbagai upaya hukum yang harus diberikan oleh aparat penegak hukum untuk memberikan rasa aman, baik secara pikiran maupun fisik, dari gangguan dan berbagai ancaman dari pihak manapun. ${ }^{18}$

Menurut pendapat Phillipus M. Hadjon bahwa perlindungan hukum bagi rakyat sebagai tindakan pemerintah yang bersifat preventif dan represif. Perlindungan hukum yang bersifat preventif dapat mencegah terjadinya sengketa, yang mengarah pada tindakan pemerintah bersikap hati-hati dalam merumuskan sebuah keputusan yang bersifat diskresi, dan perlindungan yang represif bertujuan untuk menyelesaikan terjadinya sangketa, hingga pada proses di pengadilan. ${ }^{19}$

Kaitannya dengan Proses atau pendampingan hukum terhadap Anak yang mengalami dan berhadapan langsung dengan hukum ada kecenderungan tidak terdapatnya pelayanan yang maksimal dari Pemerintah Daerah. Hal tersebut dapat dilihat dari pembentukan Pusat Pelayanan Terpadu Perlindungan Perempuan dan Anak P2TP2A di Kabupaten Halmahera Utara yang hanya di isi oleh seorang petugas, itupun hanya sebagai Relawan karena keterpanggilan moril bersangkutan dengan melihat para anak yang cenderung tidak diperhatikan dan terkesan pembiaran. Sehingga setiap kasus kekerasan anak kadang tidak tersentuh secara menyuluruh, karena bersangkutan merangkap seluruh tugas baik Pelayanan Hukum, Pendampingan Sosial dan lainnya sebagaimana diamanatkan dalam Peraturan Menteri Negara Pemberdayaan Perempuan dan Perlindungan Anak Nomor 5 tahun 2010, berikut petikan wawancara singkat dengan bersangkutan saat ditemui pada sidang pemerkosaan anak dibawah umur pada pengadilan Negeri Tobelo.

"Iya saya di SK-kan oleh Bupati, namun segala tugas yang saya emban telah merangkap dengan tugas-tugas lainnya dan saya tidak diberikan upah hanya keterpanggilan moril atas fakta anak yang jarang disentuh. Waktu tahun sebelumnya ada uang jalan namun mungkin saat ini Covid 19 sehingga tidak ada”.

16. Sibhiharta, Moralitas Hukum Dalam Hukum Praksis Sebagai Suatu Keutamaan, Jurnal Hukum dan Peradilan, Volume 4, Nomor 3, 2015: hlm. 388

17. Sukitman Asgar, Kebijakan Produk Hukum pada Pelaksanaan Pemungutan dan Perhitungan Suara Pemilu 2019, Jurnal Hibualamo Vol. 3 Nomor 2 tahun 2019, hlm. 119

18. Dyah Permata Budi Asri. Perlindungan Hukum Preventif terghadap ekspresi budaya tradisional di daerah Istimewa Yogyakkarta berdasarkan UU nomor 28 tahun 2014 tentang hak cipta. Journal of intectual property, Vol. 1 No. 1 tahun 2018 , hlm. 16

19. Philipus M. Hadjon. Perlindungan Hukum Bagi Rakyat Indonesia: Sebuah Studi Tentang Prinsip-Prinsipnya, Penanganannya Oleh Pengadilan Dalam Lingkungan Peradilan Umum Dan Pembentukan Peradilan Administrasi. Peradaban, 2017, hlm. 2 
Dari pernyataan diatas, dapat diketahui bahwa segala kebijakan yang dilakukan oleh pemerintah dalam upaya melindungi dan memenuhi hak-hak anak di Halmahera Utara belumlah maksimal. Sekalipun seluruh perangkat infrastruktur perlindungan anak telah terpenuhi, namun tidak didukung dengan personil yang menggerakan dan melaksanakan kebutuhan dan pelayanan terhadap anak adalah hal yang sia-sia. Bagaimana mungkin sekelas daerah dengan beragam corak dan geografis yang jauh dan luas antar satu dengan lainnya dengan memiliki Anggaran Pendapatan Daerah yang triliyunan hanya dikerjakan oleh seorang petugas dengan dana yang pas-pasan bahkan harus merogeh koceh sendiri, belum lagi harus berhadapan dengan para anak dengan watak dan perilaku serta usia perkembangan yang berbeda-beda dengan banyaknya personil dengan anggaran yang memadai pun belumlah tentu berhasil. Sehingga perlunya keberanian dan perhatian serius pemerintah daerah dengan cara penambahan personil serta anggaran yang memadai guna efektifitas pelayanan anak lebih baik, sebagaimana diungkapkan oleh Muhammad joni dan tanamas bahwa Kompleksitas masalah anak bersinggungan dengan struktur dan sistem yang berkembang, yang berjalan dan ditetapkan dalam suatu institusi, pemerintah bahkan negara. Dinamika yang berjalan dalam satu institusi, pemerintah atau negara akan menentukan bentuk dan karakteristik permasalahan anak. Oleh karena itu, masalah anak mencakup beberapa hal, yaitu:

1. Visi mengenai pembangunan yang berpihak kepada kepentingan anak dan yang mengutamakan kepentingan terbaik bagi anak yang terintegrasi ke dalam sistem dan model pembangunan.

2. Sistem hukum perlindungan anak belum sepenuhnya terintegrasi ke dalam norma hukum positif dan penegakan hukum anak belum maksimal.

3. Realitas anak-anak yang berada dalam situasi sulit seperti pekerja anak, anak jalanan, anak korban kekerasan, penyalahgunaan anak, pelacuran anak, dan sejumlah masalah anak-anak lainnya memerlukan intervensi khusus, karena semakin nyata ditemukan dalam masyarakat dan negara Indonesia. ${ }^{20}$

Anak merupakan sebuah aset negara dan tongkat estafet bangsa, didalam diri anaklah nantinya diharapkan mengganti dan mengisi pos-pos penting yang ditinggalkan oleh orang-orang sebelumnya atau berusia tua yang hidup lebih dulu. Namun demikian, akhir-akhir ini kekerasan terhadap anak semakin hari makin meningkat dan kebanyakan pelakunya adalah orang dewasa dan tak sedikit pula sesama anak-anak yang berujung pada proses peradilan terhadap mereka, karena terjadinya suatu akibat hukum. Anak yang berhadapan dengan hukum adalah karena adanya peristiwa pidana yang ia perbuat yang disebut pelaku tindak pidana anak, adanya perbuatan pidana yang dilakukan seseorang atau kelompok dan intansi negara terhadapnya yang disebut korban, serta suatu peristiwa hukum yang ia rasakan dan melihat sendiri yang disebut dengan saksi. Kaitan dengan hal itu Pasal 1 ayat (1) undang-undang nomor 11 tahun 2012 tentang Sistem Peradilan Pidana Anak menyatakan bahwa "Anak yang Berhadapan dengan Hukum adalah anak yang berkonflik dengan hukum, anak yang menjadi korban tindak pidana, dan anak yang menjadi saksi tindak pidana.

Hak-hak anak jauh sebelumnya telah menjadi konsen negara-negara dibelahan dunia hingga melahirkan yang disebut dengan Konvensi Hak Anak Internasional atau dikenal dengan UN-CRC (United Nations Convention on Right of the Child). Instrumen Hukum Terkait anak yang dikenal dengan Resolusi PBB Nomor 44/25 tanggal 5 Desember 1989 ini merupakan sebuah perjanjian Internasional negara-negara dunia untuk menjamin hak hak anak bidang sipil, politik, sosial, ekonomi, kesehatan maupun budaya yang diratifikasi oleh Bangsa Indonesia pada tahun 1990 melalui Keputusan Presiden Nomor 39 tahun 1990 tentang pengesahan Convention on Right of the Child. Menurut Setya Wahyudi bahwa hak-hak anak secara umum dapat dikelompokkan dalam 4 (empat) kategori hak-hak anak yaitu: hak untuk kelangsungan hidup (the right to survival), hak untuk tumbuh kembang (the right to develop), hak untuk perlindungan (the right to protection), dan hak untuk partisipasi (the right to participation). ${ }^{21}$

Tren Kasus Kekerasan Anak setiap tahun makin meningkat di Kabupaten Halmahera Utara yang pada tahun 2019 ke tahun 2020 perbandingan kenaikannya 20-25\% dengan 21 kasus ditahun 2019 dan 24 kasus pada tahun 2020 yang baru memasuki bulan september, hal ini yang tampak dipermukaan atau yang dilaporkan ke Dinas P3A dan KB serta Polres Halmahera Utara, belum pada kasus yang terendap yang tidak dilaporkan masyarakat. Berikut Grafik Kekerasan Anak di Kab. Halmahera Utara

20. Tedy Sudrajat, Perlindungan Hukum terhadap anak sebagai Hak Azasi Manusia, Kanun Jurnal Hukum, No. 54 th IXXX, 2011, hlm. 112

21. Dony Pribadi, Perlindungan Terhadap Anak Berhadapan Dengan Hukum, Mimbar Hukum, Vol. 3 No. 1 tahun 2018, hlm 21 
Sukitman Asgar dan Sahrestia Kartianti, Kebijakan Pemerintah Daerah dalam Penanganan dan Perlindungan Anak yang Berhadapan dengan Hukum di Halmahera Utara

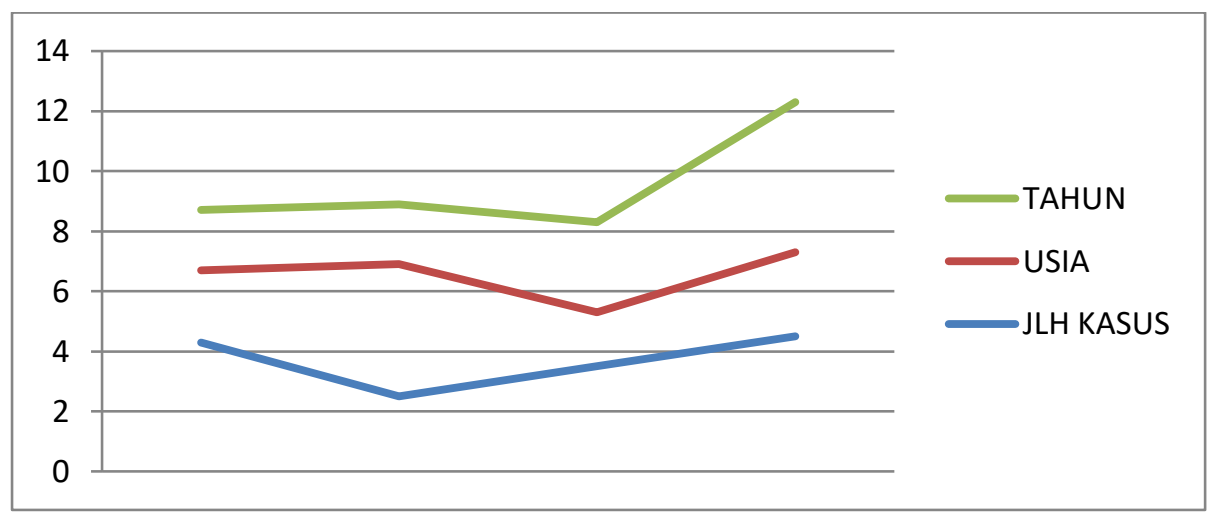

Ket: — Warna Orange adalah Perbandingan kasus setiap tahun

Warna Merah adalah Kategori Usia Korban

Warna Biru adalah Jumlah Kasus

\section{Sumber: $\quad$ Hasil telaah dan wawancara dari berbagai Sumber/Instansi Penelitian}

Kecenderungan kenaikan ini terdapat pengaruh yang berbeda dari wawanacara dengan berbagai stakholder, misalnya Pemerintah Daerah melalui Kapala Bidang Perlindungan Anak Dinas P3A dan KB Syarifa Hi. Ahmad menyatakan bahwa pengaruh dari peningkatan kekerasan anak akibat karena anak yang dititipkan pada kakek dan nenek mereka karena kedua orang tua keluar daerah untuk berkerja sehingga rentan untuk terjadi kekerasan semisalnya persetubuhan dan lainnya. Sementara Kapala Unit PPA Polres Halmahera Utara Yuwinda R. Sonoto menyatakan, Pengaruh Kekerasan Anak tiap tahun meningkat alasannya karena Berpacaran dan nikah dini. Lain hal dengan Unit Pelayanan Terpadu Anak Pemda Halmahera Utara Elisabeth Nuru menyatakan bahwa alasannya karena mabuk akibat pengaruh minuman keras, apalagi daerah ini Minuman Keras Sageru dan Cap Tikus yang sulit diberantas dan seakan telah menjadi budaya baik anak-anak maupun orang dewasa. Hal inilah menurutnya rentan dan sangat berpengaruh pada perbuatan kekerasan bila telah dikuasai minuman keras. ${ }^{22}$

Yuwinda R Sonoto menyatakan bahwa, ada beberapa kasus yang telah dilaporkan ke Polres harus dicabut oleh keluarga korban sendiri alasan karena Ekonomi, misalnya Kasus Pelecehan Anak kandung sendiri, saat keluarga korban melaporkan kasus tersebut tidak lama kemudian dicabut dan hanya diwajibkan wajib lapor dengan alasan bersangkutan orang tua bapaknya sebagai si pelaku merupakan tulang punggung keluarga, yang berdampak pada kehidupan keluarga korban, ibu, adik dan kakaknya yang lain sehingga diadakan damai. Artinya dari sini kita dapat mengetahui bahwa tidak ada perlindungan sosial dari pemerintah atas kejadian yang dialami oleh para anak, harusnya pemerintah memberikan santunan agar kehidupan dan ekonomi keluarga dalam keadaan aman sehingga tidak mengakibatkan sampai terjadi kecemasan atas kebutuhan ekonomi yang berujung pada pencabutan laporan atas perbuatan pelaku sebagaimana ditentukan dalam pasal 23 UU nomor 35 tahun 2014.

Dari berbagai kasus yang berhadapan dengan hukum menurut Dinas P3A dan KB Pemerintah Daerah Kabupaten Halmahera Utara bahwa selalu diberikan pendampingan secara intens terhadap mereka yang mengalami dan berhadapan dengan hukum, namun bantuan hukum sebagai Penasehat tidak disediakan. Hal ini bertolak belakang dengan ketentuan Undang-undangg nomor 35 tahun 2014 yang mewajibkan setiap anak yang berhadapan dengan hukum seyogyanya dibantu dengan menyediakan jasa hukum atau pendampingan pada semua tingkatan peradilan baik kepolisian, kejaksaan hingga pada tingkatan persidangan di pengadilan.

Undang-undang nomor 11 tahun 2012 tentang Sistem Peradilan Pidana Anak memberikan batasan terkait dengan anak yang berhadapan dengan hukum yaitu:

1. Anak yang Berkonflik dengan Hukum yang selanjutnya disebut Anak adalah anak yang telah berumur 12 (dua belas) tahun, tetapi belum berumur 18 (delapan belas) tahun yang diduga melakukan tindak pidana.

2. Anak yang Menjadi Korban Tindak Pidana yang selanjutnya disebut Anak Korban adalah anak yang belum berumur 18 (delapan belas) tahun yang mengalami penderitaan fisik, mental, dan/atau kerugian ekonomi yang disebabkan oleh tindak pidana.

3. Anak yang Menjadi Saksi Tindak Pidana yang selanjutnya disebut Anak Saksi adalah anak yang belum berumur 18 (delapan belas) tahun yang dapat memberikan keterangan guna kepentingan penyidikan, penuntutan

Kaitan dengan hal tersebut, semestinya lembaga peradilan baik kepolisian, kejaksaan, pengadilan hingga pada lembaga pemasyarakatan perlunya memperhatikan segala hak azasi yang dimiliki si anak sebagaiman ketentuan perundang-undangan salah satu contohnya adalah tindakan restorative justicie terhadap anak sebagai pelaku, bila si

22. Hasil Wawancara Penulis dengan Pemda Halut, Polres dan Unit P2TP2A dengan waktu yang berbeda 
anak bukanlah seorang residevils yang melibatkan semua pihak untuk mencari solusi terbaik melalui kesepakatan bersama atau musyawarah, hal ini dilakukan semata-mata untuk melindungi kepentingan para anak. Hal yang sama pun dilakukan terhadap anak sebagai korban maupun saksi suatu peristiwa, bahwa anak korban harus menadapatkan perlindungan dan pemenuhan segala hak-haknya agar tumbuh kembang anak tidak terganggu akibat malu dan lainnya, sehingga perlunya diberikan proses rehablitasi melalui medis maupun terapi sosial untuk memulihkan kondisi korban atas segala luka dan derita serta kerugian lainnya yang ia alami.

Seringkali pada proses disemua tingkatan peradilan baik Kepolisian, Kejaksaan maupun Pengadilan cukup melelahkan para anak dan mengundang kerugian baik ekonomi maupun waktu bermain sianak. Sebagaimana pernah terjadi terhadap perkara anak sebagai saksi dan korban pada perkara persetubuhan yang disidangkan di Pengadilan Negeri Tobelo saksi diminta datang oleh Jaksa sejak jam 10.00 WIT ia menunggu tanpa informasi ternyata jam 14. 00 baru dimulainya persidangan. Hal ini perlunya butuh perhatian bersama, sehingga diharapkan proaktif Pemerintah daerah untuk membangun sinergitas dan kordinasi yang baik agar anak-anak tidak menambah beban trauma yang lebih terhadap apa yang mereka alami sebelumnya.

Dalam ketentuan Pasal 3 UU Nomor 35 tahun 2014 menegaskan, setiap anak yang berhadapan dengan hukum berhak mendapatkan bantuan hukum, baik sebagai korban, saksi maupun pelaku yang kemudian diperkuat dengan ketentuan UU perlindungan Anak menjadi kewajiban Pemerintah dan Lembaga terkait untuk memberikan Perlindungan terhadap anak yang berhadapan dengan hukum sebagaimana ditegaskan dalam Pasal 59 ayat (1) dan ayat (2) b serta pasal 59A dan Pasal 60 ayat 1 poin (c).

Dalam Pasal 59

1) Pemerintah, Pemerintah Daerah, dan lembaga negara lainnya berkewajiban dan bertanggung jawab untuk memberikan Perlindungan Khusus kepada Anak.

2) Perlindungan Khusus kepada Anak sebagaimana dimaksud pada ayat (1) diberikan kepada:

a. Anak dalam situasi darurat;

b. Anak yang berhadapan dengan hukum;

Dalam pasal 64 undang-undang Perlindungan Anak menyatakan, Perlindungan Khusus bagi Anak yang berhadapan dengan hukum sebagaimana dimaksud dalam Pasal 59 ayat (2) huruf b dilakukan melalui:

a. perlakuan secara manusiawi dengan memperhatikan kebutuhan sesuai dengan umurnya;

b. pemisahan dari orang dewasa;

c. pemberian bantuan hukum dan bantuan lain secara efektif;

d. pemberlakuan kegiatan rekreasional;

e. pembebasan dari penyiksaan, penghukuman, atau perlakuan lain yang kejam, tidak manusiawi serta merendahkan martabat dan derajatnya;

f. penghindaran dari penjatuhan pidana mati dan/atau pidana seumur hidup;

g. penghindaran dari penangkapan, penahanan atau penjara, kecuali sebagai upaya terakhir dan dalam waktu yang paling singkat;

Bertalian dengan pengaturan hukum sebagaimana disebutkan diatas, sudah barang tentu menjadi kewajiban pemerintah untuk berupaya semaksimal mungkin dalam merumuskan kebijakan untuk memberikan kenyamanan terhadap anak yang berhadapan dengan hukum dengan memberikan pendampingan hukum terhadap mereka baik sebagai korban, pelaku maupun saksi dalam proses pada setiap tingkatan.

Khusus Kabupaten Halmahera Utara, anak yang berhadapan dengan hukum rata-ratanya merupakan korban dan tidak ada satupun merupakan pelaku kekerasan terhadap anak, hal itu berdasarkan hasil penelitian yang penulis lakukan pada beberapa instansi yang yaitu Dinas P3A dan KB, Polres Halut, Pengadilan Negeri Tobelo maupun Aktivis dan Pemerhati Anak seperti PPA LBH Rakyat Halut. Untuk anak yang berhadapan dengan Hukum ditangani langsung oleh P2TP2A Pusat Pelayanan Terpadu Perlindungan Perempuan dan Anak, hanya saja Petugas P2TP2A hanya terdapat seorang yang melayani setiap Anak yang berhadapan dengan hukum, yang mana pekerjaannya hanyalah suka rela untuk membantu penanganan anak yang berhadapan dengan hukum, karena tidak mendapatkan biaya dari Pemerintah Daerah yang belum lagi dengan bidang pelayanan yang banyak sehingga terkesan tidak efektif misalnya pelayanan dibidang psikososial, kesehatan maupun proses hukum anak yang berhadapan dengan hukum. Hal ini tidak sejalan dengan Peraturaan Meneteri Pemberdayaan Perempuan dan Perlindungan Anak Nomor 1 tahun 2010 tentang Standar Pelayanan Minimu Korban Kekerasan Perempuan dan Anak yang kemudian diperkuat pula dengan Peraturaan Meneteri Nomor 2 tahun 2011 tentang Pedoman Penanganan Anak Korban Kekerasan, yang mengatur tata cara pelayanan serta langkah-langkah melakukan pendampingan sosial konseling, Kesehatan Anak dan bantuan terhadap anak yang berhadapan dengan hukum.

Dalam Pasal 14 Peraturan Menteri Perlindungan Anak Nomor 6 tahun 2015 menyatakan bahwa P2TP2A adalah salah satu bentuk unit pelayanan terpadu, yang berfungsi sebagai Pusat informasi bagi perempuan dan anak, pusat 
pelayanan bagi perempuan dan anak korban kekerasan dan pusat pemberdayaan bagi perempuan dan anak. Sementara dalam pasal 15 mengatur tentang Struktur Kelembagaan P2TP2A yaitu

1. Dibentuk berdasarkan Keputusan Gubernur/Bupati/ Walikota/Camat;

2. Keanggotaan berasal dari unsur struktural dan non struktural yang berasal dari kalangan profesi, akademisi, tokoh masyarakat; dan

3. Sumber biaya pembentukan, pengembangan dan penguatan P2TP2A Provinsi Kabupaten, Kota , dan Kecamatan bersumber dari Anggaran Pendapatan dan Belanja Daerah(APBD) dan/ atau sumber lainnya yang tidak mengikat berdasarkan ketentuan peraturan perundang-undangan.

Bertalian dengan hal tersebut, menurut penulis bahwa segala upaya dan kebijakan yang diambil oleh Pemerintah daerah pada bidang perlindungan anak khususnya yang berhadapan dengan hukum terkesan hanyalah asalasalan yang seperti menjalankan sebuah proyek infrastruktur negara, dimana asal program yang dicanangkan telah dijalankan selanjutnya terserah masyarakat, mau ikut atau tidak mau taati atau tidak semua terserah masyarakat sendiri tanpa pelaksanaan strategi lainnya untuk bagaimana mencari solusi atas setiap permasalahan yang dihadapi anak maupun masyarakat itu sendiri. Masyarakat yang hanya dijadikan objek kebijakan oleh Pemerintah daerah inilah yang seringkali setiap kebijakan tidak berdampak signifikan terhadap perubahan perilaku dan pola pikir akibat kondisi sosial dan ekonomi yang berbeda.

Atas hal itu, Pemerintah Daerah dalam hal ini Bupati Halmahera Utara, seyogyanya menjadikan anak sebagai subjek kebijakan dengan melibatkan mereka pada hal-hal positif serta perlunya secara serius menangani dan melayani setiap anak untuk mendapatkan perlindungan terutama terhadap mereka yang berhadapan dengan hukum maupun korban kekerasan dengan menganggarkan anggaran kepada Dinas P3A dan KB maupun Pusat Pelayanan Terpadu Perlindungan Perempuan dan Anak, agar para anak di kabupaten Halmahera Utara dapat terlayani secara lancar dan maksimal baik batin/psikisnya maupun mereka yang berhadapan dengan hukum, apalagi situasi dan kondisi kekerasan anak di Kabupaten Halmahera Utara setiap tahun semakin meningkat yang di jugte dengan Darurat Kekerasan Anak yang nantinya berdampak terhadap tidak layaknya setiap anak tumbuh dan berkembang di daerah ini. kekhawatiran dan ketakutan itu perlunya disikapi serius oleh Pemerintah Daerah agar dapat memberikan pelayanan yang maksimal terhadap para Anak baik sebagai Korban maupun Pelaku. Sehingga tujuan Pembangunan Berkelanjutan di bidang Perlindungan Anak pun dapat tercapai (SDGs) sebagaimana dicanangkan oleh Negara-negara dibelahan dunia. ${ }^{23}$

\section{SIMPULAN}

Berdasarkan Pembahasan yang diuuraikan sebelumnya, adapun kesimpulannya yaitu tidak adanya Keseriusan Pemerintah Daerah dalam upaya melakukan pendampingan dan perlindungan terhadap anak khususnya yang berhadapan dengan hukum. Hal tersebut dapat dilihat dari minimnya pelayanan yang diberikan Dinas P3A dan KB melalui P2TP2A, sehingga dapat berpengaruh pada psikis dan mental korban kekerasan anak di Kabupaten Halmahera Utara

\section{Saran}

Perlunya perumusan kebijakan strategis oleh pemerintah daerah, salah satu dengan membuat produk hukum Peraturan Daerah untuk mengikat seluruh pihak termasuk larangan produksi dan peredaran Minuman Keras yang dilakukan melalui pendekatan dan kondisi sosial, budaya dan ekonomi masyarakat, termasuk intens melakukan kordinasi dengan penegak hukum untuk sinergitas pelayanan terhadap korban maupun pelaku kekerasan Anak. Serta perlunya sebuah Tim Tugas yang dikelola langsung Gubernur sebagai wakil pemerintah Pusat untuk mempermudah kontrol terhadap satuan pemerintah daerah Kabupaten Kota khususnya bidang Pelayanan Perlindungan Anak berdasarkan ketentuan perundang-undangan.

\section{DAFTAR PUSTAKA \\ Buku-buku}

Busrizalti H.M. Hukum Pemda Otonomi Daerah dan Implikasinya. Yokyakarta: Total Media, 2013.

Fauzan, dan Ahmad Kamil. Hukum Perlindungan dan Pengangkatan Anak di Indonesia. Jakarta: Raja Grafindo Persada, 2008.

Philipus, M. Hadjon. Perlindungan Hukum Bagi Rakyat Indonesia: Sebuah Studi Tentang Prinsip-Prinsipnya, Penanganannya Oleh Pengadilan Dalam Lingkungan Peradilan Umum Dan Pembentukan Peradilan Administrasi. Peradaban, 2007.

23. Bandingkan dengan Pernyataan KementerianPPA https://www.kemenpppa.go.id/kemen-pppa-komitmen-berikanlayanan-perlindungan-terstandar-dan-berkualitas-bagi-perempuan-dan-anak-korban-kekerasan diakses pada tanggal 13/10/2020 pukul 22.00 WIT 
Sukitman Asgar dan Sahrestia Kartianti, Kebijakan Pemerintah Daerah dalam Penanganan dan Perlindungan Anak yang Berhadapan dengan Hukum di Halmahera Utara

Rasidji, Lili. Dasar-dasar Filsafat Hukum. Bandung: Citra Aditya, 1999.

Soekanto, Soerjono. Pengantar Penelitian Hukum. Jakarta: UI Press, 2014.

Sri, Pamudji dan Soerjono Soekanto. Penelitian Hukum Normatif suatu Tinjauan Singkat. Jakarta: Raja Grafindo Persada, 2012.

Sutedjo, Wagiati. Hukum Pidana Anak. Bandung: Refika Adytama, 2010.

\section{Jurnal Ilmiah Online}

Ardianto, Syaifullah Yophi. "Perlindungan Hukum Terhadap Anak sebagai Korban dari Tindak Pidana Perdagangan Orang Di Kota Pekanbaru”, Jurnal Ilmu Hukum. Vol. 3 No. 1. (tahun 2013). 12

Asgar, Sukitman. "Penyelenggaraan Pemerintahan Daerah berdasarkan Pasal 18 UUD tahun 1945 Jo UU Nomor 23 tahun 2014 tentang Pemerintahan Daerah”, Jurnal Hibualamo, Vol. 1, No.1, (tahun 2017). 1

Asgar, Sukitman. "Kebijakan Produk Hukum pada Pelaksanaan Pemungutan dan Perhitungan Suara Pemilu 2019", Jurnal Hibualamo Vol. 3 No. 2, (tahun 2019). 119

Asri, Dyah Permata Budi. 2018, "Perlindungan Hukum Preventif terghadap ekspresi budaya tradisional di daerah Istimewa Yogyakkarta berdasarkan UU nomor 28 tahun 2014 tentang hak cipta", Journal of intectual property, Vol. 1 No. 1, (tahun 2018). 16

Lestari, Anggun. "Perlindungan Hukum Preventif Terhadap Kekerasan Perempuan Dan Anak Dalam Perspektif Hukum Hak Asasi Manusia", Marwah: Jurnal Perempuan, Agama dan Jender. Vol. 16, No. 2, (tahun 2017). 122

Pribadi, Dony. "Perlindungan Terhadap Anak Berhadapan Dengan Hukum", Mimbar Hukum, Vol. 3 No. 1, (tahun 2018). 21

Rizki, Azelia Felda. "Perlindungan Hukum terhadap Anak sebagai Korban Kekerasan yang terjadi di Sekolah", Jurnal Wajah Hukum Vol. 4 No. 1 (tahun 2020). 173

Sibhiharta. "Moralitas Hukum Dalam Hukum Praksis Sebagai Suatu Keutamaan", Jurnal Hukum dan Peradilan, Vol. 4, No. 3, (tahun 2015). 388

Sudrajat, Tedy. "Perlindungan Hukum terhadap anak sebagai Hak Azasi Manusia', Qanun Jurnal Hukum, No. 54 th IXXX, (tahun 2011). 112

\section{Surat Kabar/ Eksopedia Media Online}

Muhammad Baendi, Kekerasan Anak di Halut terus Meningkat, Terbit 31/03/2019 Harian.Halmahera.com diakses pada $10 / 08 / 2020$

Aris Mardika Sirait, Halmahera Utara Darurat Pelanggaran Anak. Terbit 21/09/2017 Nusantara.News.com, diakses pada $12 / 08 / 2020$

Egbert Hoata, Maraknya Kekerasan di Halmahera Utara, LBH meminta Penegak Hukum bertindak, terbit 07/04/2020 RadioSyalom.com Diakses pada 10/09/2020

KementerianPPA. Komitmen Berikan Layanan Perlindungan terstandar dan berkualitas bagi Anak dan Perempuan. Terbit 08/10/2018, KemenPPA.com, Diakses pada 13/10/2020

\section{Peraturan Perundang-undangan}

Konvensi Hak-Hak Anak Internasional (United Nations Convention on Right of the Child) Nomor 44/25 5 Desember 1989

Peraturaan Menteri Pemberdayaan Perempuan dan Perlindungan Anak Nomor 1 tahun 2010 tentang "Standar Pelayanan Minimal Bidang Layanan Terpadu Bagi Perempuan dan Anak Korban Kekerasan”.

Peraturan Menteri Negara Pemberdayaan Perempuan dan Perlindungan Anak Nomor 5 tahun 2010 tentang "Panduan Pembentukan dan Pengembangan Pusat Pelayanan Terpadu dengan Rahmat Tuhan Yang Maha Esa".

Peraturan Menteri Negara, Pemberdayaan Perempuan dan Anak Nomor 2 tahun 2011 tentang "Pedoman Penangan Anak Korban Kekerasan”.

Peraturan Menteri Pemberdayaan Perempuan dan Perlindungan Anak Nomor 6 tahun 2015 tentang "Sistem Pemberdayaan Perempuan dan Perlindungan Anak”.

Undang-Undang Dasar Tahun 1945 beserta Perubahannya

Undang-undang Nomor 23 tahun 2014 tentang "Pemerintahan Daerah".

Undang-undang Nomor 23 tahun 2002 tentang "Perlindungan Anak sebagaimana diubah terakhir dengan Undangundang Nomor 35 tahun 2014".

Undang-undang Nomor 11 tahun 2012 tentang "Sistem Peradilan Pidana Anak di Indonesia". 
Sukitman Asgar dan Sahrestia Kartianti, Kebijakan Pemerintah Daerah dalam Penanganan dan Perlindungan Anak yang Berhadapan dengan Hukum di Halmahera Utara

\section{Hasil Wawancara}

Wawancara dengan Ibu Syarifa Hi. Ahmad, Kapala Bidang Perlindungan Anak Dinas Pemberdayaan Perempuan, Perlindungan Anak dan Keluarga Berencana Kabupaten Halmahera Utara. tanggal 06/09 2020

Wawancara dengan Ibu Elizabeth Noru, Petugas "Pusat Pelayanan Terpadu Perlindungan Perempuan dan Anak Kabupaten Halmahera Utara, 16/09/2020

Wawancara dengan Ibu Yuwinda Sonoto, Kapala Unit PPA Polres Halmahera Utara 28/09/2020

Wawancara dengan Bapak Egbert Hoata, Pemerihati masalah Anak sekaligus Direktur LBH Rakyat Halut tanggal $25 / 09 / 2020$

Wawancara dengan Pengadilan Negeri Tobelo 